\title{
Effect of the level and type of starchy concentrate on tissue lipid metabolism, gene expression and milk fatty acid secretion in Alpine goats receiving a diet rich in sunflower-seed oil
}

\author{
L. Bernard*, C. Leroux, J. Rouel, M. Bonnet and Y. Chilliard \\ INRA, UR 1213 Herbivores, Site de Theix, F-63122 Saint-Genes-Champanelle, France \\ (Submitted 2 March 2011 - Final revision received 24 June 2011 - Accepted 30 June 2011 - First published online 30 August 2011)
}

\section{Abstract}

The potential benefits on human health have prompted an interest in developing nutritional strategies for reducing saturated and increasing specific unsaturated fatty acids (FA) in ruminant milk. The impact of the level and type of starchy concentrate added to diets supplemented with sunflower-seed oil on caprine milk FA composition and on mammary, omental and perirenal adipose, and liver lipid metabolism was examined in fourteen Alpine goats in a replicated $3 \times 3$ Latin square with $21 \mathrm{~d}$ experimental periods. Treatments were a grass hay-based diet with a high level of forage (F) or a high level of concentrate with either maize grain (CM) or flattened wheat (CW) as source of starch and supplemented with $130 \mathrm{~g} / \mathrm{d}$ sunflower-seed oil. Milk yield was enhanced $(P<0 \cdot 01)$ and milk fat content was decreased on the $\mathrm{CM}$ and $\mathrm{CW}$ diets compared with the F diet, resulting in similar milk fat secretion. Both high-concentrate diets increased $(P<0.05)$ milk yield of 10:0-16:0 and decreased trans-9,11-18:1 and cis-9,trans-11-18:2. The CW diet decreased $(P<0 \cdot 05)$ the output of $\Sigma$ C18 and $\Sigma$ cis-18:1 and increased (P<0.05) the output of trans-10-18:1 in milk. The expression and/or activity of fourteen proteins involved in the major lipogenic pathways in mammary tissues and of lipogenic genes in adipose and liver tissues were similar among treatments. In conclusion, high starch concentrates alter milk FA yield via mechanisms independent of changes in mammary, liver or adipose tissue lipogenic gene expression. Furthermore, data provided indications that mammary lipogenic responses to starchrich diets differ between caprine and bovine ruminants.

\section{Key words: Starchy concentrates: Plant oil: Goat milk: Lipogenic gene expression}

Milk fat is an important determinant of milk nutritional quality. Certain SFA (mainly 12:0, 14:0 and 16:0) are considered to exert negative effects when consumed in excess, whereas others ( $4: 0$, anteiso-15:0, cis-9-18:1 and 18:3n-3) have potentially positive effects on human health ${ }^{(1)}$. For example, cis-9,trans-11, the major isomer of conjugated linoleic acid (CLA) in ruminant milk, exhibits anticarcinogenic and antiatherogenic properties in animal models ${ }^{(2)}$. Furthermore, it is well established that nutrition is a major factor that determines the concentration and secretion of specific fatty acids (FA) in ruminant $\operatorname{milk}^{(3)}$.

FA secreted in milk originate from de novo synthesis in the mammary gland and from the uptake of TAG and NEFA from arterial blood. Milk fat synthesis is known to involve the coordinated expression of several lipogenic genes ${ }^{(4)}$, but the impact of nutrition on the regulation of mammary lipogenesis is not fully known ${ }^{(5)}$. Indeed, studies on the nutritional regulation of mammary lipogenic gene expression in lactating cows have, in the main, involved investigations examining the response to diets containing high proportions of concentrates and/or plant oils and marine lipids ${ }^{(6-9)}$. These experiments that induce milk fat depression (MFD) have provided evidence that specific biohydrogenation intermediates, namely the trans-FA isomers and mainly the trans-10 family formed during ruminal metabolism of dietary unsaturated FA, alter mammary lipid metabolism and gene expression ${ }^{(10)}$ In addition, it has long been recognised that MFD in the bovine alters nutrient partitioning in favour of non-mammary

Abbreviations: $A C A C A$, acetyl-CoA carboxylase; $A G P A T 1,1$-acyl-sn-glycerol-3-phosphate acyltransferase $\alpha$; $B T N 1 A 1$, butyrophilin subfamily 1 member A1; $\mathrm{CM}$, diet with a high level of concentrate with maize grain as source of starch and supplemented with sunflower-seed oil; $C D 36$, platelet glycoprotein 4 CLA, conjugated linoleic acid; CW, diet with a high level of concentrate with flattened wheat as source of starch and supplemented with sunflower-seed oil; $D G A T 1$, diacylglycerol acyltransferase 1; F, diet with a high level of forage and supplemented with sunflower-seed oil; FA, fatty acids; FABP3, fatty acidbinding proteins in heart; FABP4, fatty acid-binding proteins in adipocyte; FAS, fatty acid synthase; G3PDH, glycerol-3-phosphate dehydrogenase; G6PDH, glucose-6-phosphate dehydrogenase; GLYCAM1, glycosylation-dependent cell adhesion molecule 1; LPL, lipoprotein lipase; ME, malic enzyme; MFD, milk fat depression; MFG, milk fat globule; MFGE8, lactadherin; MUC1, mucin-1; PPIA, cyclophilin A; SCD, stearoyl-CoA desaturase; XDH, xanthine dehydrogenase/oxidase.

*Corresponding author: L. Bernard, fax +33 473624519, email laurence.bernard@clermont.inra.fr 
tissues, adipose tissues in particular ${ }^{(11)}$. These findings suggest that intermediary metabolism together with mammary lipogenesis may be altered by trans-FA isomers formed during the ruminal biohydrogenation of dietary unsaturated FA and/or that of other mechanisms, such as elevated ruminal propionate and plasma insulin concentration induced by high-concentrate diets, could also be involved.

In lactating goats, data on the role of nutrition in mammary metabolism and in the expression of genes encoding for key lipogenic enzymes are relatively scarce. Previous studies of these questions have only examined the effect of plant oils on either grass hay-based diets ${ }^{(12-14)}$ or maize silage-based diets $^{(15)}$. Furthermore, indirect comparisons between the goat and the cow have identified species-specific differences in the responses of milk fat secretion and composition to high-concentrate diets rich in starch and supplemented with plant oils. In particular, these comparisons have demonstrated that MFD is absent in the goat ${ }^{(3)}$. The responses of both intermediary and mammary metabolism in the goat, a species that does not exhibit MFD in response to starch-rich diets supplemented with plant oil $^{(5,10)}$, are much lower in extent than the corresponding responses in the cow. However, the effect of variable dietary starch content and degradability has not been evaluated.

The present experiment examined the effect of the level of concentrate and the type of starchy concentrate on lipogenic gene expression in mammary and peripheral tissues during established lactation in goats. These investigations sought the following: (1) to understand possible mechanisms regulating mammary lipogenesis on diets containing different levels and types of starch and supplemented with plant oil and (2) to assess the possible contribution of adipose and liver tissues to changes in milk FA secretion. Sunflower-seed oil was selected as the source of $18: 2 n-6$. The selected sources of starch were either maize grain or flattened wheat reported, respectively, as slowly and rapidly degradable sources of starch in the bovine ${ }^{(16)}$ and caprine ${ }^{(17)}$. The study sought to test the following hypothesis: the level and source of starch in diets containing $18: 2 n-6$ from sunflower-seed oil would increase specific trans intermediates formed in the rumen, resulting in different combinations of trans-11 and trans-10 isomers, with these isomers, in cows, being involved in different ways in the regulation of lipogenic gene expression, lipogenic enzyme activities and milk fat secretion ${ }^{(9)}$. The subsequent hypothesis was that the mammary lipid synthesis and intermediary lipid metabolism could be modified by the type of starchy concentrate with such modifications that could result from possible variations in trans-FA synthesised in the rumen and/or from possible variations in the concentrations of plasma insulin and metabolites.

\section{Materials and methods}

\section{Animals and diets}

All experimental procedures were approved by the Animal Care Committee of INRA in accordance with the 'Use of Vertebrates for Scientific Purposes Act' 1985. The animals were recruited to experiments and allocated to treatment groups according to milk yield, milk fat and protein content, parity, stage of lactation and genotype score at the $\alpha S 1$-casein locus. Goats of the 'middle-type' $\alpha S 1$-casein genotype content were used to avoid any effects on milk traits ${ }^{(18)}$ or FA composition $^{(19)}$. A total of fifteen multiparous (3.1 (SD 1.2) lactations) Alpine goats in mid-lactation (91 (SD 7.7) $\mathrm{d}$ in lactation) were given three experimental diets according to a replicated $3 \times 3$ Latin square design with $21 \mathrm{~d}$ experimental periods, with five groups of three animals each. From the fifteen goats recruited, one animal was withdrawn from the experiment due to mammary cysts. Each experimental period consisted of a $14 \mathrm{~d}$ adaptation to treatments (which was sufficient to achieve a full response of milk FA secretion in goats) ${ }^{(3)}$ and a $7 \mathrm{~d}$ sampling period. Goats were housed in a metabolism unit in individual stalls. The animals were allowed continuous access to water and were milked at 08.00 and 16.00 hours. Experimental diets were formulated to meet energy and protein requirements ${ }^{(20)}$. The three diets were offered as two equal meals at 08.30 and 16.30 hours. Diets were comprised of natural grassland hay that was offered ad libitum, with either a high level of forage $(0.8 \mathrm{~kg} / \mathrm{d})$ and supplemented with $130 \mathrm{~g} / \mathrm{d}$ sunflower-seed oil (F; 6.9\% of diet DM; sunflower-seed oil from Auvergne Trituration, Lezoux, France), or a high level of concentrate $(1.4 \mathrm{~kg} / \mathrm{d})$ with maize grain (CM; $1 \mathrm{~kg} / \mathrm{d} ; 5 \cdot 4 \%$ of diet DM) or flattened wheat (CW; $1 \mathrm{~kg}$ / d; $5.5 \%$ of diet DM) as source of starch and supplemented with $130 \mathrm{~g} / \mathrm{d}$ sunflower-seed oil.

\section{Measurements and sampling}

Individual intake was recorded daily. However, only the measurements collected during the last week of each experimental period were used for statistical analysis. During each experimental period, representative samples of hay, maize grain, flattened wheat and concentrates were composited daily and stored at $-20^{\circ} \mathrm{C}$. Chemical composition of feed ingredients was determined using standard procedures ${ }^{(21)}$. Milk yields of individual goats were recorded three times per week. However, only the measurements collected during the last week of each experimental period were analysed statistically. Samples of milk were collected from all goats over four consecutive milkings starting at 08.00 hours on day 19 of each experimental period for fat, crude protein and lactose analysis. Milk fat, crude protein and lactose were determined in samples treated with preservative (potassium bichromate; Merck, Fontenay-Sous-Bois, France) by mid-infrared spectroscopy ${ }^{(21)}$. Unpreserved samples of milk were also collected over two consecutive milkings starting at 08.00 hours on day 20 of each experimental period, stored at $-20^{\circ} \mathrm{C}$, composited according to yield and analysed for the determination of FA composition $^{(22)}$. The live weight of each experimental animal was measured at the start and end of each experimental period.

Blood samples were collected on day 20 of each experimental period at 07.30 hours. Samples from the jugular vein were collected into evacuated collection tubes (Venoject; C.M.L., Nemours, France) containing potassium ethylene diamine tetra-acetic acid. Once collected, blood samples were centrifuged $\left(1500 \mathrm{~g}\right.$ for $15 \mathrm{~min}$ at $4^{\circ} \mathrm{C}$, stored at $\left.-20^{\circ} \mathrm{C}\right)$, and plasma was analysed for insulin and metabolite concentrations ${ }^{(12)}$. 
On day 21 of periods 1 and 2, mammary biopsies were obtained after morning milking for tissue RNA extraction using sterile Trucut needles (CE Sherwood Medical, Ballymoney, Northern Ireland) according to the manufacturer's instructions. Approximately $20-25 \mathrm{mg}$ of tissue were taken, rinsed in $0.9 \%$ saline sterile solution, inspected to verify tissue homogeneity and snap-frozen in liquid $\mathrm{N}_{2}$. Samples were stored at $-80^{\circ} \mathrm{C}$ before RNA extraction. Collection of tissue biopsies resulted in minimal bleeding, and milk appeared normal after one to three subsequent milkings. During this period, extreme care was taken during manual milking to remove possible blood clots lodged in the glands. No intra-mammary infections or loss of milk production were encountered following mammary tissue biopsies.

At the end of the experiment, corresponding to days 26 and 27 of the last experimental period (period 3), goats were slaughtered after morning milking. Immediately before slaughter, animals were milked to remove most of the milk in the mammary glands. Immediately after death, samples of mammary, liver, and perirenal and omental adipose tissues were collected under sterile conditions, frozen in liquid $\mathrm{N}_{2}$ and stored at $-80^{\circ} \mathrm{C}$ for RNA extraction and enzyme assays. Samples of mammary tissue were analysed for stearoyl-CoA desaturase (SCD) activity immediately after collection. Samples of perirenal and omental adipose tissues were also collected immediately after slaughter, stored at $37^{\circ} \mathrm{C}$, fixed with osmium tetra-oxide and isolated in $8 \mathrm{M}$-urea for the determination of adipocyte volume ${ }^{(23)}$

\section{Enzyme activities and quantification of mRNA abundances} by quantitative $P C R$

The enzyme activities and/or mRNA abundance of enzymes involved in the major metabolic pathways of lipogenesis, in particular the uptake and transport of FA, de novo FA synthesis and TAG synthesis, were measured in mammary, liver, perirenal and omental adipose tissues.

The following lipogenic enzyme activities were assayed in samples of mammary and/or of perirenal and omental adipose tissues: lipoprotein lipase (LPL; EC 3.1.1.34), an enzyme involved in the uptake of FA from circulating $\mathrm{TAG}^{(24)}$; fatty acid synthase (FAS; EC 2.3.1.85), acetyl-CoA carboxylase (ACC; EC 6.4.1.2), malic enzyme (ME; EC 1.1.1.40) and glucose-6-phosphate dehydrogenase (G6PDH; EC 1.1.1.49), involved in de novo lipogenesis; glycerol-3-phosphate dehydrogenase (G3PDH; EC 1.1.1.8), involved in FA esterification ${ }^{(23)}$; SCD (EC 1.14.99.5), involved in the $\Delta 9$ desaturation of $\mathrm{FA}^{(12)}$.

The mRNA abundance of the following lipogenic genes was also measured in (1) samples of mammary and/or perirenal and omental adipose and/or liver tissues: ACACA, FASN, SCD1 and $L P L$; platelet glycoprotein 4 (CD36) and fatty acidbinding proteins in heart (FABP3) and adipocyte (FABP4) involved in the uptake and intracellular transport of FA; 1-acyl-sn-glycerol-3-phosphate acyltransferase $\alpha$ (AGPAT1) and diacylglycerol acyltransferase 1 (DGAT1), involved in the esterification of FA to glycerol; (2) samples of mammary tissues: xanthine dehydrogenase/oxidase $(X D H)$, butyrophilin subfamily 1 member A1 (BTN1A1), glycosylation-dependent cell adhesion molecule 1 (GLYCAM1), lactadherin (MFGE8) and mucin-1 (MUC1), which are the major proteins of the milk fat globule (MFG) membrane; (3) samples of liver tissues: the short $(O b R a)$ and long form $(O b R b)$ of the leptin receptor involved in the signal transduction of the effect of leptin ${ }^{(25)}$, which is known to regulate SCD expression in part.

Total RNA was isolated from samples of mammary tissue using the RNeasy mini kit (QIAGEN, Inc., Courtaboeuf, France) and from samples of liver using the NucleoSpin RNA II kit (Macherey Nagel, Inc., Bethlehem, PA, USA). Total RNA extraction of perirenal and omental adipose tissues was carried out as described previously ${ }^{(26)}$. DNA contamination was removed by DNase I treatment (Amplification grade; Invitrogen, Life Technologies, Carlsbad, CA, USA) before complementary DNA synthesis. Integrity and concentration of RNA and RT-PCR were assessed as described previously ${ }^{(12)}$. mRNA abundances of FASN, ACACA, LPL, SCD1, AGPAT1 and $D G A T 1$, plus the housekeeping gene peptidyl-prolyl cis-trans isomerase A (PPIA) or cyclophilin A were quantified in duplicate by real-time quantitative RT-PCR using fluorescent TaqMan probes (Applied Biosystem, Warrington, UK) and a LightCycler System (Roche Molecular Biochemicals, Indianapolis, IN, USA) using specific primers and probes (Table 1). The abundances of FABP3, FABP4, XDH, BTN1A1, MFGE8, $M U C 1, O b R a$ and $O b R b$ mRNA were quantified in duplicate by RT-PCR using the fluorescent SYBR Green I methodology (Applied Biosystem) and specific primers reported in Table 1. The abundance of targeted gene transcripts was expressed as the mRNA copy number relative to PPIA (housekeeping gene) to account for variations in RNA integrity, RNA quantification and complementary DNA synthesis.

PCR efficiency was 95.6 (SD 9.5) \% for the fourteen target genes and 95.5 (SD 1.5) \% for PPIA.

\section{Statistical analysis}

Measurements of DM intake, milk production, milk composition, FA secretion in milk, mammary mRNA abundance and plasma metabolite concentrations were subjected to ANOVA for a $3 \times 3$ Latin square design using the General Linear Models Procedure of SAS (SAS Institute, Cary, NC, USA) with a model that included the effects of treatment, period and goat. Treatment means were compared using the least-square means procedure (SAS Institute), with differences declared significant at $P<0 \cdot 05$. Measurements of enzyme activity and mRNA abundance in samples of mammary, liver, and perirenal and omental adipose tissues collected at slaughter were evaluated statistically using the non-parametric Wilcoxon $U$ test due to the small set of data $(n<6)$ and high individual variability. Treatment effects were considered significant at $P<0 \cdot 05$.

\section{Results}

\section{Diet composition}

The crude protein, neutral-detergent fibre and acid-detergent fibre content of the diets are described in Table 2. The starch content of the two high-concentrate diets (CM and 
Table 1. Primer and probe sequences and conditions used for real-time RT-PCR

\begin{tabular}{|c|c|c|c|c|c|}
\hline Gene symbol & Encoded protein & Accession no. & Nucleotide sequence $\left(5^{\prime} \rightarrow 3^{\prime}\right)$ & $T\left({ }^{\circ} \mathrm{C}\right)$ & Source \\
\hline ACACA & Acetyl-CoA carboxylase & NM_001009256 & $\begin{array}{l}\text { F: CAT GGA AAT GTA CGC GGA CC } \\
\text { R: GGT GGT AGA TGG GAA GGA GGA } \\
\text { P: CGA GCG GAA GGA GCT GGA GAG CA }\end{array}$ & 59 & Bernard et al. ${ }^{(12)}$ \\
\hline$L P L$ & Lipoprotein lipase & AF228667 & $\begin{array}{l}\text { F: TTC AGA GGC TAT TAC TGG AAA TCC } \\
\text { R: ATG TCA ATC ACA GCA TTC ATT CTA CT } \\
\text { P: TTC CAG TGG TGC CGG AAC ACT CCT TC }\end{array}$ & 60 & Bonnet et al. ${ }^{(26)}$ \\
\hline FASN & Fatty acid synthase & DQ223929 & $\begin{array}{l}\text { F: ACA GCC TCT TCC TGT TTG ACG } \\
\text { R: CTC TGC ACG ATC AGC TCG AC } \\
\text { P: ATC TGG AGG CGC GTG TGG CAG CC }\end{array}$ & 60 & Bernard et al. ${ }^{(12)}$ \\
\hline AGPAT1 & $\begin{array}{l}\text { 1-Acyl-sn-glycerol- } \\
\text { 3-phosphate } \\
\text { acyltransferase } \alpha\end{array}$ & AF281677 & F: AGT GGT GCA TCA GAC ACT TCT A & 58 & Ollier et al. ${ }^{(4)}$ \\
\hline & & & $\begin{array}{l}\text { R: CTC ACG GTT GAG CAC GTA GTA } \\
\text { P: TGG CTG TCA CTC ATC ATC GGG CA }\end{array}$ & & \\
\hline DGAT1 & $\begin{array}{l}\text { Diacylglycerol } \\
\text { O-acyltransferase } 1\end{array}$ & NM_174693 & $\begin{array}{l}\text { F: AGT GGT GCA TCA GAC ACT TCT A } \\
\text { R: CTC ACG GTT GAG CAC GTA GTA } \\
\text { P: TGG CTG TCA CTC ATC ATC GGG CA }\end{array}$ & 58 & Ollier et al. ${ }^{(4)}$ \\
\hline$S C D 1$ & $\begin{array}{l}\text { Stearoyl-CoA } \\
\text { desaturase }\end{array}$ & AF325499 & $\begin{array}{l}\text { F: TGC TGA CAA CTT ATC TGG ATG C } \\
\text { R: AAG GAA TCC TGC AAA CAG CTA } \\
\text { P: CCA GAG CCT GCA GAA GTG GCT GGT ATA A }\end{array}$ & 60 & Bernard et al. ${ }^{(12)}$ \\
\hline PPIA & Cyclophilin A & XM_001252497 & $\begin{array}{l}\text { F: GGA TTT ATG TGT CCA GGG TGG TGA } \\
\text { R: CAA GAT GCC AGG ACC TGT ATG } \\
\text { P: TCT CCC CAT AGA TGG ACT TGC CAC CAG T }\end{array}$ & 60 & Bonnet et al. ${ }^{(26)}$ \\
\hline CD36 & Platelet glycoprotein 4 & X91503 & $\begin{array}{l}\text { F: ACA GAT GTG GCT TGA GCG TG } \\
\text { R: ACT GGG TCT GTG TTT TGC AGG }\end{array}$ & 58 & Ollier et al. ${ }^{(4)}$ \\
\hline FABP3 & $\begin{array}{l}\text { Fatty acid-binding } \\
\text { protein } 3 \text {, heart }\end{array}$ & ВT021486 & $\begin{array}{l}\text { F: CCT CTC CTT CCA CTG ACT GC } \\
\text { R: TTG ACC TCA GAG CAC CCT TT }\end{array}$ & 58 & Jurie et al. ${ }^{(48)}$ \\
\hline FABP4 & $\begin{array}{l}\text { Fatty acid-binding } \\
\text { protein } 4 \text {, adipocyte }\end{array}$ & NM_174314 & F: GGT ACC TGG AAA CTT GTC TCC & 58 & Jurie et al. ${ }^{(48)}$ \\
\hline$X D H$ & $\begin{array}{l}\text { Xanthine dehydrogenase } \\
\text { oxidase }\end{array}$ & X83508 & $\begin{array}{l}\text { R: CTG ATT TAA TGG TGA CCA CAC } \\
\text { F: GCC CTG CAG AAC ATG AAT CT }\end{array}$ & 60 & Ollier et al. ${ }^{(49)}$ \\
\hline$B T N 1 A 1$ & $\begin{array}{l}\text { Butyrophilin subfamily } 1 \\
\text { member A1 }\end{array}$ & EF102891 & $\begin{array}{l}\text { R: GCA CAA ATA CTT CCT ACA CCT } \\
\text { F: GTG GAT CTG AGC AAT TGG CAA G }\end{array}$ & 60 & Ollier et al. ${ }^{(49)}$ \\
\hline MFGE8 & Lactadherin & NM_005928 & $\begin{array}{l}\text { R: ACC CTG AGG AGA AGC AGC A } \\
\text { F: TGA GTA GGT CTG GGA TGG AC } \\
\text { R: GGA AGC TGC CTG TGT ACT CT }\end{array}$ & 60 & Ollier et al. ${ }^{(4)}$ \\
\hline MUC1 & Mucin-1 & AJ400824 & $\begin{array}{l}\text { F: GCG CTG GCC ATC ATC TAT C } \\
\text { R: CGG AAG TGG CTG CCA GGT }\end{array}$ & 60 & Ollier et al. ${ }^{(49)}$ \\
\hline$O b R a$ & Leptin receptor isoform a & AY278244 & $\begin{array}{l}\text { F: TTG AGA AGT ACC AGT TCA GTC } \\
\text { R: CAA AGA ATG TCC GTT CTC TTC }\end{array}$ & 60 & Chelikani et al. ${ }^{(25)}$ \\
\hline$O b R b$ & Leptin receptor isoform b & AB199589 & $\begin{array}{l}\text { F: GTG CCA GCA ACT ACA GAT GCT CTA C } \\
\text { R: AGT TCA TCC AGG CCT TCT GAG AAC G }\end{array}$ & 65 & Chelikani et al. ${ }^{(25)}$ \\
\hline
\end{tabular}

$T$, PCR annealing temperature; $\mathrm{F}$, forward primer; $\mathrm{R}$, reverse primer; $\mathrm{P}$, Taqman probe.

CW) was 336 and $318 \mathrm{~g} / \mathrm{kg} \mathrm{DM}$, respectively, compared with $164 \mathrm{~g} / \mathrm{kg} \mathrm{DM}$ for the $\mathrm{F}$ diet. The mean forage:concentrate ratio (on a DM basis) for the $\mathrm{F}, \mathrm{CM}$ and $\mathrm{CW}$ diets was 57:43, 37:63 and 31:69, respectively. The goats consumed 145, 147 and $123 \mathrm{~g} / \mathrm{d}$ of total C18-FA and 318, 749 and $655 \mathrm{~g} / \mathrm{d}$ of starch for the F, CM and CW diets, respectively (Table 3 ).

\section{Animal performance}

Even though the consumption of concentrate rich in maize grain increased the DM intake $(P=0.003)$, the calculated energy and $\mathrm{N}$ balance were positive for all the experimental treatments (Table 3). The calculated energy balance increased $(P<0.001)$ with the $\mathrm{CM}$ and $\mathrm{CW}$ diets, compared with the $\mathrm{F}$ diet (Table 3). There were no changes in body weight according to treatments (results not shown), which is not surprising since the length of the experimental periods was only 3 weeks. Relative to the $\mathrm{F}$ diet, the $\mathrm{CM}$ and $\mathrm{CW}$ diets enhanced milk yield $(+500$ and $+620 \mathrm{~g} / \mathrm{d}$, respectively; $P<0 \cdot 001)$, milk protein yield $(+19$ and $+22 \mathrm{~g} / \mathrm{d}$, respectively; $P=0 \cdot 04)$ and milk lactose yield ( +25 and $+31 \mathrm{~g} / \mathrm{d}$, respectively; $P<0.001$ ) without changing milk fat yield. Conversely, relative to the F diet, the CM and CW diets decreased milk fat content $(-4.1$ and $-4.4 \mathrm{~g} / \mathrm{kg}$, respectively; $P=0.003)$, whereas no effect $(P>0.05)$ was observed for milk protein and lactose content (Table 3).

\section{Plasma metabolites}

Both high-concentrate diets increased plasma glucose concentrations, whereas plasma insulin concentration increased only 
Table 2. Ingredient and chemical composition of the experimental diets

\begin{tabular}{|c|c|c|c|}
\hline \multirow[b]{2}{*}{ Items } & \multicolumn{3}{|c|}{ Treatment } \\
\hline & $\mathrm{F}$ & $\mathrm{CM}$ & $\mathrm{CW}$ \\
\hline \multicolumn{4}{|l|}{ Ingredients (\% DM) } \\
\hline Natural grassland hay & $57 \cdot 7$ & $36 \cdot 8$ & $31 \cdot 1$ \\
\hline Sunflower-seed oil* & 6.9 & 5.4 & 5.5 \\
\hline Maize grain & $10 \cdot 8$ & $45 \cdot 3$ & 0.0 \\
\hline Flattened wheat & $10 \cdot 3$ & 0.0 & $51 \cdot 0$ \\
\hline Dehydrated sugar beet pulp & $2 \cdot 1$ & 4.0 & 3.9 \\
\hline Soyabean meal & $12 \cdot 4$ & 8.5 & $9 \cdot 2$ \\
\hline Mineral-vitamin mix $\dagger$ & 0.5 & 0.5 & 0.5 \\
\hline \multicolumn{4}{|l|}{ Chemical composition (g/kg DM) } \\
\hline Organic matter & 912 & 928 & 923 \\
\hline Crude protein & 180 & 149 & 170 \\
\hline Neutral-detergent fibre & 388 & 333 & 274 \\
\hline Acid-detergent fibre & 197 & 145 & 134 \\
\hline Starch & 164 & 336 & 318 \\
\hline Total FA & 86 & 75 & 67 \\
\hline Diethyl ether extract & 89 & 84 & 74 \\
\hline
\end{tabular}

$F$, diet with a high level of forage and supplemented with sunflower-seed oil; $\mathrm{CM}$, diet with a high level of concentrate with maize grain as source of starch and supplemented with sunflower-seed oil; CW, diet with a high level of concentrate with flattened wheat as source of starch and supplemented with sunflower-seed oil; FA, fatty acids.

* Sunflower-seed oil contained (g/100 g FA) 16:0 (6.8), 18:0 (3.8) cis-9-18:1 (30.5), 18:2n-6 (57.9) and 22:0 (0.3).

† Mineral-vitamin supplement (Usine d'Ussel, Murat, France) contained $(\mathrm{g} / \mathrm{kg}$ ): Ca, 240; P, 60; Mg, 50; Na, 15; Zn, 7; Mn, 6; DL- $\alpha$-tocopherol, 0.3; retinol, 0.2; cholecalciferol, 0.002 .

when the concentrate was rich in maize grain (CM; Table 4). Compared with the $\mathrm{F}$ diet, the $\mathrm{CM}$ diet decreased plasma NEFA concentrations. Furthermore, the CM diet increased plasma acetate, whereas no effect was observed on $\beta$-hydroxybutyrate content (Table 4).

\section{Mammary, adipose tissue and liver lipid metabolism}

Dietary treatments had no effect $(P>0.05)$ on the abundance of mRNA in mammary tissue encoding for lipogenic genes (LPL, ACACA, FASN, SCD1, AGPAT1, DGAT1, CD36, FABP4 and $F A B P 3$ ) and for MFG proteins (XDH, BTN1A1, GLYCAM1, MFGE8 and MUC1) (Table 5). However, a significant $(P=0.01)$ and close $(R>+0.60)$ inter-individual relationship between the mRNA abundances was observed only for the following five pairs of genes: $A C A C A$ and FASN, BTN1A1 and $X D H, X D H$ and DGAT1, DGAT1 and FABP4, SCD1 and AGPAT1 (Fig. 1).

In perirenal and omental adipose tissues, the treatments had no effect $(P>0.05)$ on the abundance of mRNA encoding for $L P L, F A S N, A C A C A$ and AGPAT1 (Table 6), except for a decrease in FASN mRNA and an increase in AGPAT1 mRNA for the CM diet in omental adipose tissue. In the liver, SCD1 mRNA increased with the CM diet (Table 6). Furthermore, dietary treatments had no effect $(P>0.05)$ on LPL, FAS, G6PDH, ME and G3PDH activities in perirenal and omental adipose tissues (Table 7), as well as in mammary tissues, with the exception of a decrease $(P<0.05)$ in G3PDH for the CM diet compared with the CW diet. SCD and ACC activities in mammary tissues were not affected by the dietary treatments (Table 7).

\section{Milk fatty acid secretion}

A high level of concentrate in the diet increased $(P<0.001)$ the milk secretion of C6- to C14-SFA and cis-9-14:1 and 16:0 secretion. These increases were associated with a decrease $(P<0 \cdot 001)$ in the output of trans-9-16:1, trans-9, 11-18:1 and cis-9,trans-11-18:2 in milk (Table 8). Relative to the $\mathrm{F}$ diet, decreases in the milk fat trans-11-18:1 and cis-9,trans-11-18:2 secretions were -67 and $-63 \%$, respectively, for the $\mathrm{CW}$ diet and -32 and $-36 \%$, respectively, for the $\mathrm{CM}$ diet. Relative to the $\mathrm{F}$ diet, the milk fat medium-chain FA (C10- to C16-SFA) and cis-9-14:1 secretions were higher, and higher for the CW diet than for the CM diet (Table 8). The inclusion of flattened wheat as a type of starch in the high-concentrate diet (CW) resulted in increases $(P<0.05)$ in milk trans-10-18:1, $18: 2 n-6$ and $18: 3 n-3$ output and decreases $(P<0 \cdot 05)$ in milk cis-9-18:1 and $\Sigma$ C18 output, compared with the CM and $\mathrm{F}$ diets (Table 8 ).

The consumption of the CM or CW diet had no significant effect $(P>0 \cdot 15)$ on milk fat $\Delta 9$ desaturase ratios (cis-914:1:14: 0 , cis-9-16:1:16:0 and cis-9-18:1:18:0) except for an increase in the cis-9,trans-11-CLA:trans-11-18:1 concentration ratio for the $\mathrm{CW}$ diet, compared with the $\mathrm{F}$ and $\mathrm{CM}$ diets (Table 8).

\section{Discussion}

\section{DM intake and milk production and composition}

In goats, the observed milk and protein yield increases in response to the addition of starchy concentrate to a lipidrich diet (Table 3) are consistent with the results of previous studies $^{(3,27)}$. The increase in milk yield in response to the addition of starchy concentrate was associated with (1) a higher yield of lactose in milk in agreement with previous studies $^{(27)}$, consistent with the role of lactose in the regulation of milk osmolarity ${ }^{(28)}$ and (2) the increased DM intake and energy intake (results not shown) for the CM diet.

The increase in dietary concentrate and starch content in the presence of sunflower-seed oil in the present experiment had no effect on milk fat yield, whereas it decreased milk fat concentration, probably owing to a dilution effect. In contrast, in cows fed diets supplemented with linseed oil $^{(29)}$ or 'corn oil' (30), increasing the level of dietary concentrate from 36 to $66 \%{ }^{(29)}$ and from 50 to $80 \%{ }^{(30)}$ decreased the milk fat yield by 42 and $55 \%$, respectively. In goats, increasing the percentage of concentrate in a lipid-supplemented diet up to $69 \%$ (present study), $65 \%{ }^{(27)}$ or $68 \%{ }^{(3)} \mathrm{did}$ not change or increased milk fat secretion. Otherwise, in cows, feeding starch-based diets that differed by the source of starch (cracked wheat $v$. potatoes) showed that the quicker ruminal degradation of wheat starch was associated with a decrease in milk fat ${ }^{(31)}$. Altogether these results highlight the differences between ruminant species in ruminal kinetics or metabolism and in the regulation of mammary lipid metabolism. The mechanisms underlying this species difference remain largely unknown. 
Table 3. Effect of the level and type of starchy concentrate in diets supplemented with sunflower-seed oil on DM intake, milk yield, milk composition, and calculated energy and protein balance in goats

(Mean values with their standard errors, $n$ 42; error $\mathrm{df}=24$ )

\begin{tabular}{|c|c|c|c|c|c|}
\hline \multirow[b]{2}{*}{ Items } & \multicolumn{3}{|c|}{ Treatment } & \multirow[b]{2}{*}{ SEM } & \multirow[b]{2}{*}{$P$} \\
\hline & $\mathrm{F}$ & $\mathrm{CM}$ & CW & & \\
\hline DM intake $(\mathrm{kg} / \mathrm{d})$ & $1.94^{\mathrm{a}}$ & $2 \cdot 23^{b}$ & $2 \cdot 06^{a}$ & 0.048 & 0.003 \\
\hline \multicolumn{6}{|l|}{ Intake $(g / d)$} \\
\hline $14: 0$ & $0.36^{a}$ & $0.30^{b}$ & $0.25^{c}$ & 0.009 & $<0.001$ \\
\hline $16: 0$ & $15 \cdot 3^{\mathrm{a}}$ & $16 \cdot 0^{\mathrm{a}}$ & $12 \cdot 5^{\mathrm{b}}$ & 0.288 & $<0.001$ \\
\hline cis-9-16: 1 & $0.08^{b}$ & $0.09^{a}$ & $0.05^{c}$ & 0.003 & $<0.001$ \\
\hline $18: 0$ & $5 \cdot 38^{\mathrm{a}}$ & $5 \cdot 27^{\mathrm{a}}$ & $4.47^{\mathrm{b}}$ & 0.098 & $<0.001$ \\
\hline cis-9-18: 1 & $43 \cdot 3^{a}$ & $45 \cdot 7^{\mathrm{a}}$ & $36 \cdot 6^{\mathrm{b}}$ & 0.871 & $<0.001$ \\
\hline cis-11-18: 1 & $1 \cdot 14^{\mathrm{a}}$ & $1 \cdot 14^{a}$ & $0.99^{b}$ & 0.021 & $<0.001$ \\
\hline $18: 2 n-6$ & $84.1^{\mathrm{a}}$ & $86 \cdot 9^{\mathrm{a}}$ & $73 \cdot 4^{\mathrm{b}}$ & 1.669 & $<0.001$ \\
\hline $18: 3 n-3$ & $10 \cdot 83^{\mathrm{a}}$ & $8 \cdot 24^{b}$ & $6 \cdot 46^{c}$ & 0.440 & $<0.001$ \\
\hline$\Sigma C 18$ & $145^{\mathrm{a}}$ & $147^{\mathrm{a}}$ & $122^{\mathrm{b}}$ & $2 \cdot 676$ & $<0.01$ \\
\hline$\Sigma F A$ & $163^{\mathrm{a}}$ & $166^{\mathrm{a}}$ & $136^{\mathrm{b}}$ & 2.967 & $<0.001$ \\
\hline \multicolumn{6}{|l|}{ Yield $(g / d)$} \\
\hline Milk & $2660^{\mathrm{a}}$ & $3160^{b}$ & $3280^{\mathrm{b}}$ & 69.5 & $<0.001$ \\
\hline Fat & 98 & 103 & 106 & $3 \cdot 13$ & 0.13 \\
\hline Protein & $90^{\mathrm{a}}$ & $109^{b}$ & $112^{\mathrm{b}}$ & $2 \cdot 83$ & 0.04 \\
\hline Lactose & $124^{\mathrm{a}}$ & $149^{\mathrm{b}}$ & $155^{\mathrm{b}}$ & 3.47 & $<0.001$ \\
\hline \multicolumn{6}{|l|}{ Concentration $(\mathrm{g} / \mathrm{kg}$ ) } \\
\hline Fat & $36 \cdot 8^{\mathrm{a}}$ & $32 \cdot 7^{\mathrm{b}}$ & $32 \cdot 4^{\mathrm{b}}$ & 0.86 & 0.003 \\
\hline Protein & $33 \cdot 8$ & $34 \cdot 3$ & $34 \cdot 2$ & 0.30 & 0.55 \\
\hline Lactose & $46 \cdot 9$ & $47 \cdot 0$ & 47.5 & 0.27 & 0.12 \\
\hline Energy balance (MJ NEl/d)* & $1.52^{\mathrm{C}}$ & $4.03^{a}$ & $2 \cdot 47^{\mathrm{b}}$ & 0.276 & $<0.001$ \\
\hline Protein balance (PDI, g/d) ${ }^{\star}$ & 60 & 47 & 46 & $4 \cdot 22$ & 0.06 \\
\hline \multicolumn{6}{|c|}{$\begin{array}{l}\text { F, diet with a high level of forage and supplemented with sunflower-seed oil; CM, diet with a high } \\
\text { level of concentrate with maize grain as source of starch and supplemented with sunflower-seed } \\
\text { oil; CW, diet with a high level of concentrate with flattened wheat as source of starch and sup- } \\
\text { plemented with sunflower-seed oil; FA, fatty acids; NEI, net energy of lactation; PDI, digestible } \\
\text { protein at the intestine. } \\
\text { a,b,c Mean values within a row with unlike superscript letters were significantly different }(P<0.05) \text {. } \\
{ }^{*} \text { Energy and protein balances calculated according to INRA }{ }^{(20)} \text {. }\end{array}$} \\
\hline
\end{tabular}

\section{Milk fatty acid secretion and mammary metabolism}

In the present experiment, the increased output of milk medium-chain FA $(10: 0$ to $16: 0 ;+25 \%$ with the CM diet and $+45 \%$ with the $\mathrm{CW}$ diet) with a high level of concentrate in lipid-rich diets was not accompanied by significant alterations in ACC, FAS, G6PDH, ME or G3PDH activities, nor by significant alterations in $A C A C A$ and $F A S N$ mRNA abundances. These findings can be compared with previous studies in goats on response to plant lipids ${ }^{(12,15)}$ where decreases in milk medium-chain FA secretion $(-18$ to $-27 \%)$ were not accompanied by changes in mammary lipogenic gene expression or activity. Altogether these data suggest that, in the caprine, changes in milk medium-chain FA in response to dietary treatments are not mediated by changes in lipogenic gene expression or ex vivo enzyme activity.

The secretion of long-chain FA ( $\Sigma$ C18) in response to the addition of starch to the diet was maintained (CM) or slightly decreased (CW) (Table 8). These low variations in milk C18-FA secretion were not accompanied by variations

Table 4. Effect of the level and type of starchy concentrate in diets supplemented with sunflower-seed oil on plasma insulin and metabolite concentrations in goats

(Mean values with their standard errors, $n 42$; error $\mathrm{df}=24$ )

\begin{tabular}{lcccccc}
\hline & \multicolumn{5}{c}{ Treatment } \\
\cline { 2 - 4 } Items & $\mathrm{F}$ & $\mathrm{CM}$ & $\mathrm{CW}$ & SEM & $P$ \\
\hline Insulin (pmol/l) & $97.9^{\mathrm{b}}$ & $131.3^{\mathrm{a}}$ & $122.2^{\mathrm{a}, \mathrm{b}}$ & 10.21 & 0.05 \\
Glucose (mM) & $3.23^{\mathrm{b}}$ & $3.44^{\mathrm{a}}$ & $3.44^{\mathrm{a}}$ & 0.039 & 0.002 \\
NEFA (mM) & $0.32^{\mathrm{a}}$ & $0.15^{\mathrm{b}}$ & $0.24^{\mathrm{a}, \mathrm{b}}$ & 0.030 & 0.005 \\
Acetate (mM) & $0.26^{\mathrm{b}}$ & $0.36^{\mathrm{a}}$ & $0.26^{\mathrm{b}}$ & 0.020 & 0.002 \\
3-Hydroxy-butyrate (mM) & 0.20 & 0.23 & 0.21 & 0.021 & 0.55 \\
\hline
\end{tabular}

$\mathrm{F}$, diet with a high level of forage and supplemented with sunflower-seed oil; CM, diet with a high level of concentrate with maize grain as source of starch and supplemented with sunflower-seed oil; CW, diet with a high level of concentrate with flattened wheat as source of starch and supplemented with sunflower-seed oil.

a,b Mean values within a row with unlike superscript letters were significantly different $(P<0.05)$. 
Table 5. Effect of the level and type of starchy concentrate in diets supplemented with sunflowerseed oil on the mRNA abundance of lipogenic genes in the mammary tissue of goats (Mean values with their standard errors, $n 42$; error $\mathrm{df}=24$ )

\begin{tabular}{|c|c|c|c|c|c|c|}
\hline & \multicolumn{3}{|c|}{ Treatment } & \multirow[b]{2}{*}{ SEM } & \multirow[b]{2}{*}{ LSD† } & \multirow[b]{2}{*}{$P$} \\
\hline & $F$ & $\mathrm{CM}$ & $\mathrm{CW}$ & & & \\
\hline \multicolumn{7}{|c|}{ mRNA relative abundance* } \\
\hline$L P L$ & 4.53 & 4.56 & 4.66 & 0.409 & 1.19 & 0.97 \\
\hline$A C A C A$ & 0.756 & 0.727 & 0.818 & 0.0800 & 0.23 & 0.69 \\
\hline FASN & 8.89 & $8 \cdot 73$ & $9 \cdot 70$ & 0.985 & $2 \cdot 87$ & 0.57 \\
\hline SCD1 & 9.85 & 9.03 & 8.93 & 0.942 & 2.75 & 0.80 \\
\hline AGPAT1 & $2 \cdot 79$ & $2 \cdot 20$ & 2.45 & 0.261 & 0.76 & 0.33 \\
\hline$D G A T 1$ & 0.848 & 0.709 & 0.629 & 0.097 & 0.28 & 0.33 \\
\hline$C D 36$ & 3.40 & 3.24 & 3.14 & 0.553 & 1.24 & 0.83 \\
\hline$X D H$ & 3.22 & 3.22 & $2 \cdot 89$ & 0.436 & 1.27 & 0.84 \\
\hline BTN1A1 & 11.39 & 11.25 & 11.58 & 1.342 & 3.92 & 0.98 \\
\hline GLYCAM1 & 71.34 & $75 \cdot 99$ & 81.58 & 8.948 & $26 \cdot 21$ & 0.74 \\
\hline MFGE8 & 4.57 & 3.70 & 4.68 & 0.414 & 1.56 & 0.20 \\
\hline MUC1 & 0.094 & 0.085 & 0.106 & 0.0068 & 0.02 & 0.10 \\
\hline FABP4 & 0.325 & 0.274 & 0.264 & 0.0304 & 0.09 & 0.37 \\
\hline$F A B P 3$ & $108 \cdot 8$ & $108 \cdot 1$ & $96 \cdot 8$ & 8.980 & $26 \cdot 21$ & 0.55 \\
\hline \multicolumn{7}{|c|}{$\begin{array}{l}\text { F, diet with a high level of forage and supplemented with sunflower-seed oil; CM, diet with a high level of concentrate } \\
\text { with maize grain as source of starch and supplemented with sunflower-seed oil; CW, diet with a high level of } \\
\text { concentrate with flattened wheat as source of starch and supplemented with sunflower-seed oil; LSD, least signifi- } \\
\text { cance difference; } L P L \text {, lipoprotein lipase; } A C A C A \text {, acetyl-CoA carboxylase; FASN, fatty acid synthase; SCD1, } \\
\text { stearoyl-CoA desaturase; AGPAT1, 1-acyl-Sn-glycerol-3-phosphate acyltransferase } \alpha ; D G A T 1 \text {, diacylglycerol } \\
\text { acyltransferase 1; CD36, platelet glycoprotein } 4 ; X D H \text {, xanthine dehydrogenase/oxidase; BTN1A1, butyrophilin } \\
\text { subfamily } 1 \text { member A1; GLYCAM1, glycosylation-dependent cell adhesion molecule 1; MFGEB, lactadherin; } \\
\text { MUC1, mucin-1; FABP4, fatty acid-binding protein, adipocyte; FABP3, fatty acid-binding protein, heart. } \\
\text { * mRNA levels expressed in arbitrary units determined as abundance relative to cyclophylin A mRNA and multiplied } \\
\text { by } 100 \text {. } \\
\text { † LSD for comparison with observed non-significant differences. }\end{array}$} \\
\hline
\end{tabular}

in mammary LPL mRNA abundance and/or activity, or in mRNA abundance of genes involved in the uptake, transport and trafficking of FA in the cells (CD36, FABP3 and FABP4).

Otherwise, an absence of variation of mammary mRNA abundance for genes involved in the desaturation of FA (SCD1) or in TAG synthesis (AGPAT1 and DGAT1) following the increase of concentrate in the diet is in agreement with findings on SCD1 in previous studies. These studies have demonstrated that $S C D 1$ gene expression varies little, except when supplements rich in $n$ - 3 FA are added to the diet in the $\mathrm{cow}^{(7)}$ and the goat ${ }^{(12)}$, thereby down-regulating SCD1.

In the present experiment, no alteration of mammary mRNA abundance for genes coding for the major proteins of the MFG membrane (BTN1A1, XDH, MFGE8 and MUC1) was observed in response to the concentrate. This result is consistent with the observed absence of milk fat yield modification. However, a positive inter-individual relationship between BTN1A1 and $X D H(r+0.84, P<0.01$; Fig. 1(b)) was observed. This observation suggests the possible co-regulation of these two genes. This hypothetical co-regulation is supported by the model of secretion of $\mathrm{MFG}^{(32)}$. This model supposes that milk secretion involves a tripartite complex having the following components: the integral transmembrane protein butyroplylin; the cytoplasmic enzyme xanthine oxidoreductase $(\mathrm{XDH})$; the lipid droplet surface protein adipophilin. Overall, these results are consistent with the idea that the expression of proteins of the MFG membrane in the mammary gland is closely related to secretory activity ${ }^{(33)}$.

The present study characterised the mammary expression of fourteen genes involved in the different pathways of lipogenesis, as well as in the protein of the MFG membrane. This the first study to characterise the mammary expression of these genes in goats. The results of the study also demonstrated positive associations between the following pairs of genes: ACACA and FASN mRNA $(r+0.72$, $P<0.01$; Fig. 1(a)), as described previously ${ }^{(5)}, S C D 1$ and AGPAT1 mRNA $(r+0.60, P<0.01$; Fig. 1(e) $), D G A T 1$ and FABP4 mRNA $(r+0.71, \quad P<0.01 ;$ Fig. $1(\mathrm{~d}))$ and $X D H$ and DGAT1 mRNA $(r+0.73, P<0 \cdot 01$; Fig. $1(\mathrm{c}))$. Such relationships probably result from shared regulation by the same transcription factor or from concomitant regulation by different transcription factors ${ }^{(9)}$ for these genes or other regulatory mechanisms involving microRNA ${ }^{(34)}$.

In the present study, addition of concentrate $(+20-25 \%$ in the diet) and starch $(+16 \%$ of the DM intake) in the diet induced increases in milk medium-chain FA (10:0 to 16:0) output in goats $(+25$ and $+45 \%$, respectively, for the CM and $\mathrm{CW}$ diets), compared with a reduction of $31 \%{ }^{(29)}$ or $32 \%{ }^{(30)}$ in cows offered diets with comparable increases in concentrate $\left(+30 \%\right.$ in the diet $\left.{ }^{(29,30)}\right)$ and starch content $\left(+15 \%{ }^{(29)}\right.$ and $\left.+16 \% \mathrm{DM}^{(30)}\right)$ and supplemented with linseed oil $^{(29)}$ or "corn oil'(30) (rich in 18:2n-6 and 18:1n-9). In addition, whereas no or slight variation of $\Sigma$ C18 secretion was observed in goats (Table 8), cows fed similar diets exhibited a reduction of $53 \%^{(29)}$ or $43 \%^{(30)}$ of $\Sigma$ C18 secretion. These findings are in agreement with the lower inhibitory effect of dietary trans-10,cis-12-CLA on the uptake and incorporation of long-chain FA in goats than in cows ${ }^{(35)}$. However, direct comparisons of ruminant species fed the same diet are required to confirm these observations. 
(a)

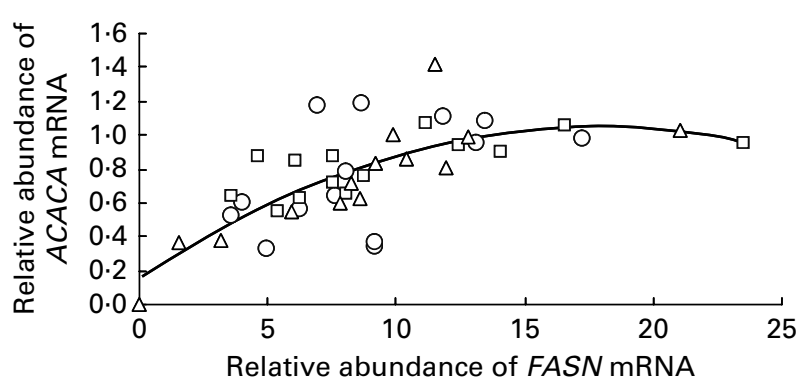

(b)

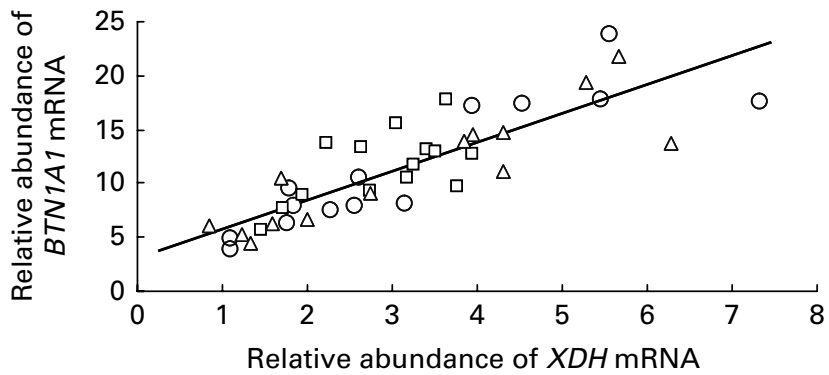

(c)

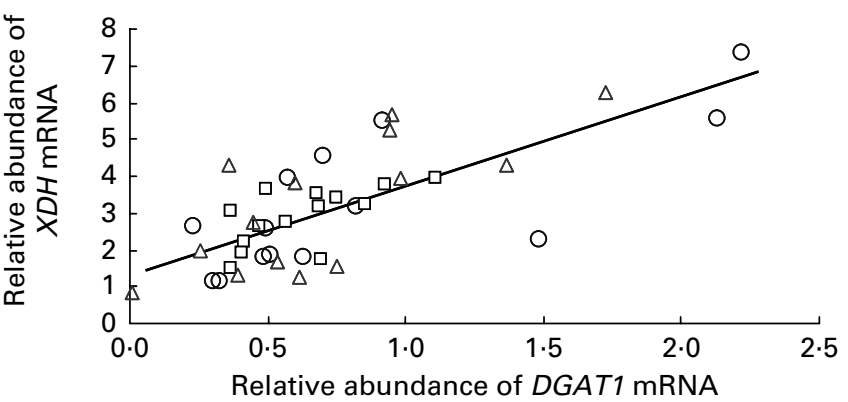

(d)

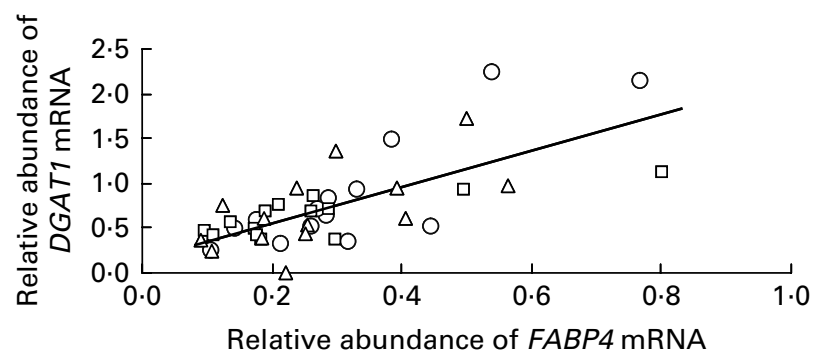

(e)

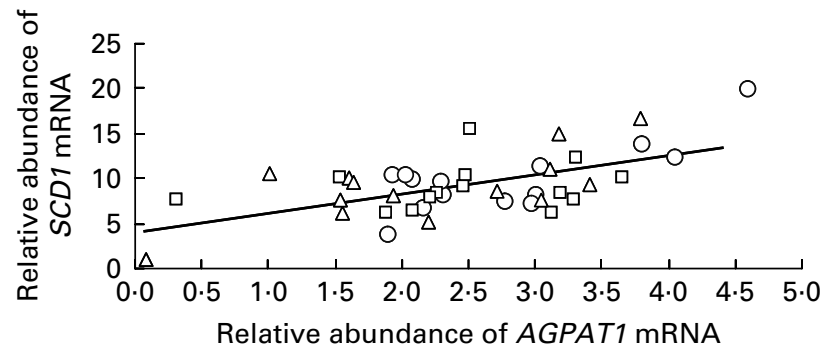

Fig. 1. Relationships between mRNA abundances of (a) acetyl-CoA carboxylase $(A C A C A)$ and fatty acid synthase $(F A S M): y=-0.0028 x^{2}+0.0999 x+0.152$; $r+0.72, n 42, P=0.01$; (b) xanthine oxidoreductase $(X D H)$ and butyrophilin (BTN1A1): $y=2.682 x+3.064 ; r+0.84, n 42, P=0.01 ;$ (c) diacylglycerol acyltransferase 1 (DGAT1) and $X D H: y=2 \cdot 405 x+1 \cdot 358 ; r+0.73, n 42, P=0.01$; (d) $D G A T 1$ and adipocyte fatty acid-binding protein $(F A B P 4): y=2 \cdot 014 x+0.150 ; r+0.71$, $n$ 42, $P=0.01$ and (e) 1-acyl-sn-glycerol-3-phosphate acyltransferase $\alpha$ (AGPAT1) and stearoyl-CoA desaturase $(S C D 1): y=2 \cdot 167 x+3.893 ; r+0.60, n 42$, $P=0.01$ in the mammary gland of goats fed a diet with a high level of forage and supplemented with sunflower-seed oil $(O)$ or a diet with a high level of concentrate with maize grain as source of starch and supplemented with sunflower-seed oil $(\triangle)$, or a diet with a high level of concentrate with flattened wheat as source of starch and supplemented with sunflower-seed oil ( $\square$ ). The mRNA abundances are expressed in arbitrary units, determined as abundance relative to cyclophylin A mRNA and multiplied by 100.

The observed differences between ruminant species in response to a high concentrate added to lipid-rich diets might be related to the following: (1) the synthesis of specific ruminal biohydrogenation intermediates known to exert antilipogenic effects; (2) species specificities in mammary lipid metabolism; and/or (3) differences in acetate and $\beta$-hydroxybutyrate supply for de novo lipid synthesis in the mammary gland.

Studies on the nutritional regulation of mammary lipogenic gene expression and enzyme activities in response to MFD diets in the lactating cow have pointed out that specific ruminal biohydrogenation intermediates may exert mammary antilipogenic effects in the bovine ${ }^{(10)}$. Those intermediates are associated with the ruminal trans-10 pathway, particularly with trans-10, cis-12-CLA that has been shown unequivocally to inhibit milk fat synthesis in ruminants (but to a lower extent in goats than in cows) ${ }^{(35)}$, although other biohydrogenation intermediates may also be involved as suggested for the cis-10, trans-12-CLA, trans-9, cis-11-CLA and trans-10$18: 1^{(10)}$. In the present experiment, mammary secretion of trans-10-18:1 attained its maximal value in response to the CW treatment and corresponded to a milk concentration of $2 \cdot 17 \%$ of total FA (results not shown). This result is in the same range as the values observed in milk from cows fed a comparable diet $\left(2 \cdot 84 \%^{(29)}\right.$ and $2 \cdot 90 \%{ }^{(30)}$ of total FA) that induced a MFD. This indirect comparison illustrates the marked differences between goats and cows in the relationship between changes in milk fat secretion and increases in milk fat trans-10-18: 1 concentration. Indeed, it has been shown that within the range of milk trans-10-18:1 concentrations 
Table 6. Effect of the level and type of starchy concentrate in diets supplemented with sunflowerseed oil on the mRNA abundance of genes involved in lipid metabolism in perirenal and omental adipose and liver tissues of goats

(Mean values with their standard errors)

\begin{tabular}{|c|c|c|c|c|c|c|}
\hline \multirow[b]{3}{*}{ mRNA relative abundance* } & \multicolumn{6}{|c|}{ Treatment } \\
\hline & \multicolumn{2}{|c|}{$\mathrm{F}(n 5)$} & \multicolumn{2}{|c|}{$\mathrm{CM}(n 4)$} & \multicolumn{2}{|c|}{$\mathrm{CW}(n 5)$} \\
\hline & Mean & SEM & Mean & SEM & Mean & SEM \\
\hline \multicolumn{7}{|l|}{ Perirenal adipose tissue } \\
\hline$L P L$ & 274.7 & $41 \cdot 7$ & $260 \cdot 4$ & $35 \cdot 1$ & $240 \cdot 5$ & $27 \cdot 8$ \\
\hline FASN & 171.0 & $60 \cdot 9$ & 429.7 & $178 \cdot 3$ & 194.4 & 37.4 \\
\hline$S C D 1$ & 3.29 & 1.36 & 5.33 & 1.72 & 3.61 & 1.32 \\
\hline AGPAT1 & 1.22 & 0.22 & 0.884 & 0.291 & 1.263 & 0.173 \\
\hline \multicolumn{7}{|l|}{ Omental adipose tissue } \\
\hline$L P L$ & $186 \cdot 9$ & $18 \cdot 4$ & $150 \cdot 4$ & 43.4 & $125 \cdot 2$ & $18 \cdot 2$ \\
\hline FASN & $224 \cdot 0^{\mathrm{a}}$ & 37.5 & $110 \cdot 1^{\mathrm{b}}$ & $15 \cdot 0$ & $102 \cdot 8^{a, b}$ & $39 \cdot 0$ \\
\hline$S C D 1$ & 4.82 & 0.80 & $5 \cdot 27$ & 1.51 & 3.92 & 1.57 \\
\hline AGPAT1 & $0.317^{\mathrm{a}}$ & 0.024 & $0.432^{b}$ & 0.027 & $0.504^{a, b}$ & 0.106 \\
\hline \multicolumn{7}{|l|}{ Liver } \\
\hline SCD1 & $5 \cdot 34^{a, b}$ & 0.85 & $6 \cdot 82^{a}$ & $1 \cdot 16$ & $3.69^{b}$ & 0.49 \\
\hline$A C A C A$ & 0.235 & 0.039 & 0.254 & 0.028 & 0.214 & 0.026 \\
\hline ObRa & 0.383 & 0.102 & 0.229 & 0.018 & $0.331 \dagger$ & 0.041 \\
\hline$O b R b$ & 0.579 & 0.258 & 0.259 & 0.131 & 0.184 & 0.047 \\
\hline
\end{tabular}

F, diet with a high level of forage and supplemented with sunflower-seed oil; CM, diet with a high level of concentrate with maize grain as source of starch and supplemented with sunflower-seed oil; CW, diet with a high level of concentrate with flattened wheat as source of starch and supplemented with sunflower-seed oil; $L P L$, lipoprotein lipase; FASN, fatty acid synthase; SCD1, stearoyl-CoA desaturase; AGPAT1, 1-acyl-sn-glycerol-3phosphate acyltransferase $\alpha$; ACACA, acetyl-CoA carboxylase; ObRa, leptin receptor isoform a; ObRb, leptin receptor isoform $b$.

${ }^{\mathrm{a}, \mathrm{b}}$ Mean values within a row with unlike superscript letters were significantly different $(P<0.05)$.

* mRNA levels expressed in arbitrary units determined as abundance relative to cyclophylin A mRNA and multiplied by 100 .

† Mean value was significantly different from the CM diet $(P<0 \cdot 10)$.

observed in goats $(0-5 \cdot 2 \%$ of total FA), almost all milk fat yield responses are positive, whereas the converse is true in cows $^{(5,10)}$. In the present study, an increase in trans-10-18:1 (from 0.88 to $2 \cdot 17 \%$ of total $\mathrm{FA}$ for the $\mathrm{F}$ and $\mathrm{CW}$ diets, respectively) was accompanied by an increase in milk medium-chain FA secretion $(\mathrm{C} 10-\mathrm{C} 16,+45 \%)$. These results suggest that trans-10-18:1 and, in general, the FA family associated with the trans-10 pathway are much less potent in caprine mammary cells in agreement with results from a study in goats receiving dietary supplements of trans-10, cis-12-CLA ${ }^{(35)}$. This finding contrasts with the observed antilipogenic activity of these compounds in the cow.

The present study also investigated the substrate supply for mammary de novo lipid synthesis. The study revealed increased or stable plasma acetate and 3-hydroxy-butyrate concentrations in response to dietary concentrate. Decreases in plasma acetate and 3-hydroxy-butyrate concentrations ${ }^{(29)}$ and decreases in acetate or stable butyrate concentrations in ruminal fluid ${ }^{(30)}$ have been observed in cows fed comparable diets. These differences between goats and cows may contribute to the increase in de novo FA synthesis in the mammary gland in goats. Moreover, these results suggest differences in the ruminal metabolism of dietary carbohydrate among ruminant species. They imply a greater stability of ruminal fermentation processes in response to various dietary conditions in goats, compared with cows ${ }^{(22)}$. Accordingly, in goats fed diets with a high level of concentrate, the nature of starchy concentrate (slowly or rapidly degradable starch) had little or no influence on the rumen fermentation parameters $^{(17)}$ (stable and high rumen $\mathrm{pH}$, volatile $\mathrm{FA}$ profile) compared with studies from bovine ${ }^{(31)}$. These differences among ruminant species could be attributed to differences in feeding behaviour ${ }^{(36)}$ : (1) a greater ingestive chewing efficiency of the goats that may explain the smaller differences between maize and wheat starch and (2) greater eating and rumination times for goats than for sheep and cows with high-concentrate diets which have been related to higher rumen-buffering capacity in goats ${ }^{(37)}$.

The present experiment demonstrated that switching from a low- to high-concentrate diet in goats receiving $18: 2 n-6$ from sunflower-seed oil does not induce MFD or variations in mammary lipogenic expression, irrespective of the source of starch in concentrate supplements.

\section{Adipose and liver lipid metabolism}

The present experiment found no changes in lipogenic gene expression and/or enzyme activity in perirenal and omental adipose tissues in response to concentrate in a lipid-rich diet. This result is in agreement with the lack of change found in milk fat secretion. In cows, high-concentrate diets have been found to induce MFD, which involves changes in biohydrogenation pathways in the rumen leading to increased level of numerous milk biohydrogenation intermediates including trans-10,cis-12-18:2. This effect was associated with less energy used for milk fat synthesis and an alteration 
Table 7. Effect of the level and type of starchy concentrate in diets supplemented with sunflower-seed oil on lipoprotein lipase (LPL), acetyl-CoA carboxylase (ACC), fatty acid synthase (FAS), glucose-6-phosphate dehydrogenase (G6PDH), malic enzyme (ME), stearoyl-CoA desaturase (SCD) and glycerol-3-phosphate dehydrogenase (G3PDH) activities in the mammary, perirenal and omental adipose tissues of goats

(Mean values with their standard errors)

\begin{tabular}{|c|c|c|c|c|c|c|}
\hline & \multicolumn{6}{|c|}{ Treatment } \\
\hline & \multicolumn{2}{|c|}{$\mathrm{F}(n 5)$} & \multicolumn{2}{|c|}{$\mathrm{CM}(n 4)$} & \multicolumn{2}{|c|}{$\mathrm{CW}(n 5)$} \\
\hline & Mean & SEM & Mean & SEM & Mean & SEM \\
\hline \multicolumn{7}{|c|}{ Activity (nmol/min per mg protein) } \\
\hline \multicolumn{7}{|c|}{ Mammary gland } \\
\hline$L P L$ & 29.5 & 3.54 & $26 \cdot 5$ & 5.58 & $26 \cdot 6$ & $5 \cdot 21$ \\
\hline$A C C$ & $12 \cdot 9$ & $1 \cdot 19$ & $15 \cdot 7$ & $4 \cdot 26$ & $16 \cdot 4$ & 3.04 \\
\hline FAS & $216 \cdot 0$ & $16 \cdot 7$ & $216 \cdot 0$ & $32 \cdot 1$ & $205 \cdot 0$ & $5 \cdot 9$ \\
\hline G6PDH & $282 \cdot 0$ & $21 \cdot 2$ & 328.0 & $21 \cdot 8$ & $314 \cdot 0$ & $26 \cdot 4$ \\
\hline$M E$ & $5 \cdot 0$ & 1.23 & 3.9 & 0.73 & 4.6 & 1.22 \\
\hline$S C D$ & 0.158 & 0.0203 & 0.150 & 0.0135 & 0.121 & 0.0179 \\
\hline G3PDH & $161 \cdot 0^{\mathrm{a}, \mathrm{b}}$ & $20 \cdot 8$ & $128 \cdot 0^{\mathrm{a}}$ & $6 \cdot 3$ & $162 \cdot 0^{\mathrm{b}}$ & 11.4 \\
\hline \multicolumn{7}{|c|}{ Activity ( $\mathrm{nmol} / \mathrm{min}$ per $10^{6}$ adipocytes) ${ }^{\star}$} \\
\hline \multicolumn{7}{|c|}{ Perirenal adipose tissue } \\
\hline$L P L$ & $33 \cdot 0$ & $8 \cdot 0$ & $29 \cdot 0$ & $8 \cdot 2$ & $21 \cdot 0$ & $6 \cdot 3$ \\
\hline FAS & $100 \cdot 0$ & $19 \cdot 3$ & 90.0 & $14 \cdot 2$ & $109 \cdot 0$ & $22 \cdot 7$ \\
\hline G6PDH & 243.0 & $39 \cdot 7$ & 296.0 & $41 \cdot 6$ & $382 \cdot 0$ & 88.2 \\
\hline$M E$ & 78.0 & $16 \cdot 4$ & $81 \cdot 0$ & $10 \cdot 3$ & $89 \cdot 0$ & $28 \cdot 6$ \\
\hline G3PDH & $5001 \cdot 0$ & 643.4 & $5112 \cdot 0$ & 653.7 & 4823.0 & 926.9 \\
\hline \multicolumn{7}{|c|}{ Omental adipose tissue } \\
\hline$L P L$ & $45 \cdot 0$ & $12 \cdot 9$ & $31 \cdot 0$ & $8 \cdot 3$ & $26 \cdot 0$ & $5 \cdot 0$ \\
\hline$F A S$ & 178.0 & 73.9 & 95.0 & $26 \cdot 4$ & 153.0 & $14 \cdot 8$ \\
\hline G6PDH & 323.0 & 47.5 & 358.0 & $49 \cdot 6$ & 528.0 & $50 \cdot 6$ \\
\hline$M E$ & 101.0 & $22 \cdot 8$ & 87.0 & $18 \cdot 7$ & $81 \cdot 0$ & $13 \cdot 8$ \\
\hline$G 3 P D H$ & 4473.0 & 867.5 & 4523.0 & 543.7 & $5702 \cdot 0$ & $762 \cdot 3$ \\
\hline
\end{tabular}

of nutrient partitioning in favour of non-mammary tissues, particularly adipose tissues ${ }^{(11,38)}$, which was accompanied by the increased transcription of genes involved in lipogenesis in subcutaneous adipose tissue ${ }^{(39)}$. The mechanisms of these differences between the responses of goat and cow adipose tissues to a high-concentrate diet remain to be unravelled but could be related to differences in plasma insulin concentrations or in the synthesis of specific ruminal biohydrogenation intermediates, as discussed in the previous section.

Lipogenic activities in adipose tissue were not altered in response to the increased level of concentrate in the diets. Indeed, the absence of change in these lipogenic activities occurred despite the slightly higher plasma insulin and glucose concentrations and calculated energy balance that are known to be involved in the regulation of adipose tissue lipogenesis ${ }^{(40)}$. However, it is likely that the significantly elevated calculated energy balance and plasma glucose and insulin concentrations observed for the CM diet may have contributed to the inhibition of the lipolytic pathways in adipose tissue ${ }^{(41,42)}$, as suggested by the lower plasma NEFA concentration found with this diet, without being sufficient to induce lipogenesis.

Comparison of enzyme activities between tissues (Table 7) highlights their specific lipid metabolism. The study found a substantially greater activity of $\mathrm{G} 3 \mathrm{PDH}$ and $\mathrm{ME}$ in perirenal and omental adipose tissues compared with the mammary gland, whereas the activities of LPL, FAS and G6PDH were similar between tissues. Those results are in line with previous data for perirenal adipose tissue and mammary glands in goats fed maize silage-based diets supplemented with plant oils ${ }^{(15)}$.

In the liver, addition of concentrate in the lipid-rich diets had no effect on $A C A C A$ and SCD1 mRNA abundance, whereas the CW diet significantly decreased SCD1 mRNA abundance, compared with the CM diet. This observation, together with the higher leptinaemia reported with the CW treatment ${ }^{(43)}$, is in agreement with data from rodents demonstrating that leptin suppresses SCD1 transcription and activity in the liver $^{(44)}$. This effect may be facilitated by the observed tendency ( $P=0.08)$ towards a higher expression of the leptin receptor isoform ObRa in the $\mathrm{CW}$ treatment, compared with the $\mathrm{CM}$ treatment. This leptin receptor isoform mRNA has been characterised in the bovine and is highly expressed in the liver and spleen ${ }^{(25,45)}$. This isoform receptor could be involved in leptin transport, thereby contributing to the multiple physiological functions of leptin in ruminants ${ }^{(46)}$. To our knowledge, such relationships have not yet been reported for caprine liver. However, the role of circulating levels of leptin in the regulation of lipid metabolism in adipose and other tissues in the lactating ruminant remains unclear and needs to be clarified $^{(47)}$. 
Table 8. Effect of the level and type of starchy concentrate in diets supplemented with sunflower-seed oil on the secretion of major fatty acids (FA) in milk and milk fat $\Delta-9$ desaturase ratios in goats

(Mean values with their standard errors, $n$ 42; error $\mathrm{df}=24$ )

\begin{tabular}{|c|c|c|c|c|c|}
\hline & \multicolumn{3}{|c|}{ Treatment } & \multirow[b]{2}{*}{ SEM } & \multirow[b]{2}{*}{$P$} \\
\hline & $\mathrm{F}$ & $\mathrm{CM}$ & $\mathrm{CW}$ & & \\
\hline \multicolumn{6}{|l|}{ FA secretion $(\mathrm{g} / \mathrm{d})$} \\
\hline $4: 0$ & $1.78^{\mathrm{b}}$ & $1.99^{\mathrm{a}, \mathrm{b}}$ & $2 \cdot 11^{a}$ & 0.098 & 0.06 \\
\hline $6: 0$ & $1.91^{\mathrm{b}}$ & $2 \cdot 35^{\mathrm{a}}$ & $2 \cdot 63^{\mathrm{a}}$ & 0.125 & 0.002 \\
\hline $8: 0$ & $1.69^{c}$ & $2 \cdot 19^{\mathrm{b}}$ & $2 \cdot 61^{a}$ & 0.139 & $<0.001$ \\
\hline $9: 0$ & $0.09^{b}$ & $0 \cdot 13^{a}$ & $0 \cdot 12^{\mathrm{a}}$ & 0.011 & 0.03 \\
\hline $10: 0$ & $5 \cdot 38^{\mathrm{a}}$ & $7 \cdot 22^{\mathrm{b}}$ & $9 \cdot 01^{\mathrm{c}}$ & 0.414 & $<0.001$ \\
\hline cis-9-10: 1 & $0 \cdot 14^{\mathrm{C}}$ & $0 \cdot 19^{\mathrm{b}}$ & $0.22^{\mathrm{a}}$ & 0.010 & $<0.001$ \\
\hline $11: 0$ & $0 \cdot 12^{\mathrm{b}}$ & $0 \cdot 19^{\mathrm{a}}$ & $0 \cdot 19^{a}$ & 0.016 & 0.007 \\
\hline $12: 0$ & $2 \cdot 60^{c}$ & $3.73^{b}$ & $4 \cdot 50^{\mathrm{a}}$ & 0.174 & $<0.001$ \\
\hline $13: 0$ & $0 \cdot 18^{b}$ & $0.25^{a}$ & $0.25^{a}$ & 0.014 & $<0.001$ \\
\hline iso- $14: 0$ & $0 \cdot 10$ & 0.13 & 0.11 & 0.010 & 0.20 \\
\hline $14: 0$ & $6 \cdot 65^{\mathrm{c}}$ & $8 \cdot 81^{\mathrm{b}}$ & $10 \cdot 09^{\mathrm{a}}$ & 0.418 & $<0.001$ \\
\hline cis-9-14:1 & $0.08^{\mathrm{c}}$ & $0 \cdot 12^{\mathrm{b}}$ & $0 \cdot 14^{\mathrm{a}}$ & 0.007 & $<0.001$ \\
\hline iso-15: 0 & $0 \cdot 19$ & 0.18 & $0 \cdot 18$ & 0.010 & 0.61 \\
\hline anteiso-15:0 & $0.34^{\mathrm{b}}$ & $0.39^{\mathrm{a}, \mathrm{b}}$ & $0.43^{\mathrm{a}}$ & 0.022 & 0.04 \\
\hline $15: 0$ & $0.86^{b}$ & $1 \cdot 01^{\mathrm{a}, \mathrm{b}}$ & $1.04^{a}$ & 0.055 & 0.06 \\
\hline iso- $16: 0$ & 0.24 & 0.26 & 0.30 & 0.029 & 0.33 \\
\hline $16: 0$ & $15 \cdot 68^{\mathrm{b}}$ & $18 \cdot 18^{\mathrm{a}}$ & $20 \cdot 40^{\mathrm{a}}$ & 0.792 & 0.002 \\
\hline $10: 0+12: 0+14: 0+16: 0$ & $30 \cdot 31^{c}$ & $37.95^{\mathrm{b}}$ & $44 \cdot 01^{\mathrm{a}}$ & 1.675 & 0.001 \\
\hline cis-9-16:1 & $0.41^{\mathrm{b}}$ & $0.44^{\mathrm{a}, \mathrm{b}}$ & $0.48^{\mathrm{a}}$ & 0.022 & 0.06 \\
\hline trans-9-16: 1 & $0.32^{\mathrm{a}}$ & $0.20^{\mathrm{b}}$ & $0.11^{\mathrm{c}}$ & 0.22 & $<0.001$ \\
\hline iso-17:0 & $0.40^{\mathrm{b}}$ & $0.37^{\mathrm{b}}$ & $0.48^{a}$ & 0.024 & 0.007 \\
\hline $17: 0$ & 0.35 & 0.34 & 0.40 & 0.019 & 0.11 \\
\hline $18: 0$ & $14 \cdot 14^{\mathrm{a}, \mathrm{b}}$ & $14 \cdot 87^{\mathrm{a}}$ & $12 \cdot 25^{\mathrm{b}}$ & 0.689 & 0.05 \\
\hline cis-9-18: 1 & $22.96^{\mathrm{a}}$ & $22 \cdot 42^{\mathrm{a}}$ & $19 \cdot 82^{b}$ & 0.610 & 0.007 \\
\hline$\sum$ cis-18:1 & $24 \cdot 18^{\mathrm{a}}$ & $23 \cdot 91^{\mathrm{a}}$ & $21 \cdot 14^{\mathrm{b}}$ & 0.633 & 0.01 \\
\hline trans-6,7,8-18:1 & 0.46 & 0.43 & 0.39 & 0.027 & 0.19 \\
\hline trans-9-18: 1 & $0.42^{\mathrm{a}}$ & $0.36^{\mathrm{b}}$ & $0.33^{\mathrm{b}}$ & 0.019 & 0.005 \\
\hline trans-10-18: 1 & $0.78^{b}$ & $1.04^{\mathrm{b}}$ & $2 \cdot 21^{a}$ & 0.313 & 0.01 \\
\hline trans-11-18:1 & $2 \cdot 85^{\mathrm{a}}$ & $1.94^{\mathrm{b}}$ & $0.95^{\mathrm{c}}$ & 0.208 & $<0.001$ \\
\hline trans-12-18: 1 & $0.48^{\mathrm{a}}$ & $0.48^{\mathrm{a}}$ & $0.39^{\mathrm{b}}$ & 0.025 & 0.05 \\
\hline trans-13-18: 1 & 0.29 & 0.42 & 0.42 & 0.054 & $0 \cdot 19$ \\
\hline$\sum$ trans-18:1 & $5 \cdot 33$ & 4.70 & 4.74 & 0.455 & 0.55 \\
\hline $18: 2 n-6$ & $1.98^{\mathrm{b}}$ & $2 \cdot 17^{\mathrm{b}}$ & $2 \cdot 62^{\mathrm{a}}$ & 0.115 & 0.002 \\
\hline $18: 3 n-3$ & $0.29^{\mathrm{b}}$ & $0.28^{\mathrm{b}}$ & $0.35^{\mathrm{a}}$ & 0.022 & 0.04 \\
\hline cis-9,trans-11-CLA & $1.53^{\mathrm{a}}$ & $0.98^{\mathrm{b}}$ & $0.57^{c}$ & 0.107 & $<0.001$ \\
\hline$\Sigma C 18$ & $48 \cdot 10^{\mathrm{a}}$ & $47 \cdot 61^{\mathrm{a}}$ & $42 \cdot 25^{\mathrm{b}}$ & $1 \cdot 388$ & 0.02 \\
\hline \multicolumn{6}{|l|}{$\Delta-9$ desaturase ratios } \\
\hline cis-9-14:1:14:0 & 0.013 & 0.014 & 0.014 & 0.0008 & 0.30 \\
\hline cis-9-16:1:16:0 0 & 0.027 & 0.024 & 0.024 & 0.0013 & 0.37 \\
\hline cis-9-18:1:18:0 & 1.66 & 1.56 & 1.67 & 0.056 & 0.32 \\
\hline cis-9,trans-11-CLA:trans-11-18:1 & $0.54^{\mathrm{b}}$ & $0.55^{\mathrm{b}}$ & $0.62^{\mathrm{a}}$ & 0.023 & 0.03 \\
\hline
\end{tabular}

\section{Conclusions}

Increases in the secretion of medium-chain FA in response to the level and the type of starchy concentrate added to a lipidrich diet in the goat appear to be regulated by mechanisms independent of changes in mammary lipogenic gene expression. This response in goats differs from that observed in cows. This difference between goats and cows were discussed according to the following: (1) a lower sensitivity of the mammary gland to the anti-lipogenic activity of specific trans-10 FA biohydrogenation intermediates and/or (2) increased or more stable acetate and butyrate availability which could putatively increase de novo FA synthesis in the goat mammary gland, compared with decreased availability in the cow, with these changes being probably related to different feeding behaviour. In addition, the concentrate had no effect on lipogenic gene expression and/or activity in perirenal and omental adipose and liver tissues except $S C D 1$ mRNA and a trend for ObRa in the liver. This finding is in agreement with the absence of a response of milk fat secretion to the concentrate in goats. Despite the absence of variation in the mammary gene expression of lipogenic enzymes and proteins of the MFG membrane, the data of the present study revealed positive inter-individual correlations between few pairs of genes which would need further investigations. 


\section{Acknowledgements}

This study was supported by European funding under the project EU BIOCLA (project QLK1-2002-02362). The authors gratefully acknowledge the staff of the Animal Nutrition and Metabolism Unit Les Cèdres, in particular André Combeau and Christophe Mathevon, for diligent care of the experimental animals, Roland Jailler and his team for assisting in the slaughter of the experimental animals, Philippe Gaydier and Denys Durand for the collection of the mammary biopsies, Sébastien Bes, Cyril Labonne, Pierre Capitan, Martine Tourret, Didier Bany and Cecilia Sosa for assistance with the analysis of the samples and Frédéric Glasser for advice on statistical analyses. All authors have contributed to the preparation of the paper and agree with the submitted manuscript content. L. B. and Y. C. designed the research. L. B. and J. R. performed the research, and L. B. and M. B. analysed the samples. L. B., Y. C., J. R., M. B. and C. L. analysed the data and drafted the paper. There are no conflicts of interest.

\section{References}

1. Parodi PW (2005) Dairy product consumption and the risk of breast cancer. J Am Coll Nutr 24, 556S-568S.

2. Wahle KW, Heys SD \& Rotondo D (2004) Conjugated linoleic acids: are they beneficial or detrimental to health? Prog Lipid Res 43, 553-587.

3. Chilliard Y, Glasser F, Ferlay A, et al. (2007) Diet, rumen biohydrogenation, cow and goat milk fat nutritional quality. Eur J Lipid Sci Technol 109, 828-855.

4. Ollier S, Robert-Granie C, Bernard L, et al. (2007) Mammary transcriptome analysis of food-deprived lactating goats highlights genes involved in milk secretion and programmed cell death. J Nutr 137, 560-567.

5. Bernard L, Leroux C \& Chilliard Y (2008) Expression and nutritional regulation of lipogenic genes in the ruminant lactating mammary gland. Adv Exp Med Biol 606, 67-108.

6. Piperova LS, Teter BB, Bruckental I, et al. (2000) Mammary lipogenic enzyme activity, trans fatty acids and conjugated linoleic acids are altered in lactating dairy cows fed a milk fat-depressing diet. J Nutr 130, 2568-2574.

7. Ahnadi CE, Beswick N, Delbecchi L, et al. (2002) Addition of fish oil to diets for dairy cows. II. Effects on milk fat and gene expression of mammary lipogenic enzymes. $J$ Dairy Res 69, 521-531.

8. Peterson DG, Matitashvili EA \& Bauman DE (2003) Dietinduced milk fat depression in dairy cows results in increased trans-10, cis-12 CLA in milk fat and coordinate suppression of mRNA abundance for mammary enzymes involved in milk fat synthesis. J Nutr 133, 3098-3102.

9. Harvatine KJ \& Bauman DE (2006) SREBP1 and thyroid hormone responsive spot 14 (S14) are involved in the regulation of bovine mammary lipid synthesis during diet-induced milk fat depression and treatment with CLA. J Nutr $\mathbf{1 3 6}$, $2468-2474$.

10. Shingfield KJ, Bernard L, Leroux C, et al. (2010) Role of trans fatty acids in the nutritional regulation of mammary lipogenesis in ruminants. Animal 4, 1140-1166.

11. Bauman DE \& Griinari JM (2003) Nutritional regulation of milk fat synthesis. Annu Rev Nutr 23, 203-227.

12. Bernard L, Rouel J, Leroux C, et al. (2005) Mammary lipid metabolism and milk fatty acid secretion in Alpine goats fed vegetable lipids. J Dairy Sci $\mathbf{8 8}, 1478-1489$.
13. Bernard L, Leroux C, Bonnet M, et al. (2005) Expression and nutritional regulation of lipogenic genes in mammary gland and adipose tissues of lactating goats. J Dairy Res $\mathbf{7 2}$, $250-255$.

14. Bernard L, Leroux C, Faulconnier Y, et al. (2009) Effect of sunflower-seed oil or linseed oil on milk fatty acid secretion and lipogenic gene expression in goats fed hay-based diets. J Dairy Res 76, 241-248.

15. Bernard L, Bonnet M, Leroux C, et al. (2009) Effect of sunflower-seed oil and linseed oil on tissue lipid metabolism, gene expression and milk fatty acid secretion in alpine goats fed maize silage based diets. J Dairy Sci 92, 6083-6094.

16. Sauvant D, Chapoutot P \& Archimède H (1994) La digestion des amidons par les ruminants et ses conséquences (Starch digestion by ruminants and its consequences). INRA Prod Anim 7, 115-124.

17. Archimède H, Sauvant D, Hervieu J, et al. (1996) Effects of the nature of roughage and concentrate and their proportion on ruminal characteristics of non lactating goats, consequences on digestive interactions. Anim Feed Sci Technol 58, 267-282.

18. Grosclaude F, Ricardeau G, Martin P, et al. (1994) Du gčne au fromage: le polymorphisme de la caséine alphaS1 caprine, ses effets, son évolution (From gene to cheese: caprine casein alphaS1 polymorphism, its effects and evolution). INRA Prod Anim 7, 3-19.

19. Chilliard Y, Rouel J \& Leroux C (2006) Goat's alpha-s1 casein genotype influences its milk fatty acid composition and delta-9 desaturation ratios. Anim Feed Sci Technol 131, 474-487.

20. INRA (1989) Ruminant nutrition. In Recommended Allowance and Feed Table [R Jarrige, editor]. Paris: INRA.

21. Association of Official Analytical Chemists (1997) Official Methods of Analysis, 16th ed. Gaithersburg, MD: AOAC International.

22. Bernard L, Shingfield KJ, Rouel J, et al. (2009) Effect of plant oils in the diet on performance and milk fatty acid composition in goats fed diets based on grass hay or maize silage. BrJ Nutr 101, 213-224.

23. Chilliard Y, Gagliostro G, Flechet J, et al. (1991) Duodenal rapeseed oil infusion in early and midlactation cows. 5. Milk fatty acids and adipose tissue lipogenic activities. J Dairy Sci 74, 1844-1854.

24. Faulconnier Y, Thevenet M, Flechet J, et al. (1994) Lipoprotein lipase and metabolic activities in incubated bovine adipose tissue explants: effects of insulin, dexamethasone, and fetal bovine serum. J Anim Sci 72, 184-191.

25. Chelikani PK, Glimm DR \& Kennelly JJ (2003) Short Communication: tissue distribution of leptin and leptin receptor mRNA in the bovine. J Dairy Sci 86, 2369-2372.

26. Bonnet M, Leroux C, Faulconnier Y, et al. (2000) Lipoprotein lipase activity and mRNA are up-regulated by refeeding in adipose tissue and cardiac muscle of sheep. J Nutr 130, 749-756.

27. Andrade PVD \& Schmidely P (2006) Influence of percentage of concentrate in combination with rolled canola seeds on performance, rumen fermentation and milk fatty acid composition in dairy goats. Livest Sci 104, 77-90.

28. Cant JP, DePeters EJ \& Baldwin RL (1993) Mammary amino acid utilization in dairy cows fed fat and its relationship to milk protein depression. J Dairy Sci 76, 762-774.

29. Loor JJ, Ferlay A, Ollier A, et al. (2005) Relationship among trans and conjugated fatty acids and bovine milk fat yield due to dietary concentrate and linseed oil. J Dairy Sci $\mathbf{8 8}$, $726-740$. 
30. Griinari JM, Dwyer DA, McGuire MA, et al. (1998) Transoctadecenoic acids and milk fat depression in lactating dairy cows. J Dairy Sci 81, 1251-1261.

31. Jurjanz S, Monteils V, Juaneda P, et al. (2004) Variations of trans octadecenoic acid in milk fat induced by feeding different starch-based diets to cows. Lipids 39, 19-24.

32. Mather IH \& Keenan TW (1998) Origin and secretion of milk lipids. J Mammary Gland Biol Neoplasia 3, 259-273.

33. McManaman JL, Palmer CA, Wright RM, et al. (2002) Functional regulation of xanthine oxidoreductase expression and localization in the mouse mammary gland: evidence of a role in lipid secretion. $J$ Physiol 545, 567-579.

34. Lynn FC (2009) Meta-regulation: microRNA regulation of glucose and lipid metabolism. Trends Endocrinol Metab 20, 452-459.

35. Shingfield KJ, Rouel J \& Chilliard Y (2009) Effect of calcium salts of a mixture of conjugated linoleic acids containing trans-10, cis-12 in the diet on milk fat synthesis in goats. Br J Nutr 101, 1006-1019.

36. Goetsch AL, Gipson TA, Askar AR, et al. (2010) Invited review: feeding behavior of goats. J Anim Sci 88, 361-373.

37. Desnoyers M, Giger-Reverdin S, Sauvant D, et al. (2011) The use of a multivariate analysis to study between-goat variability in feeding behavior and associated rumen $\mathrm{pH}$ patterns. J Dairy Sci 94, 842-852.

38. Griinari JM \& Bauman DE (2006) Milk fat depression: concepts, mechanisms and management applications. In Ruminant Physiology: Digestion, Metabolism and Impact of Nutrition on Gene Expression, Immunology and Stress, pp. 389-417 [K Sejrsen, T Hvelplund and MO Nielsen, editors]. Wageningen: Wageningen Academic Publishers.

39. Harvatine KJ, Perfield JW 2nd \& Bauman DE (2009) Expression of enzymes and key regulators of lipid synthesis is upregulated in adipose tissue during CLA-induced milk fat depression in dairy cows. J Nutr 139, 849-854.
40. Vernon RG (1980) Lipid metabolism in the adipose tissue of ruminant animals. Prog Lipid Res 19, 23-106.

41. Bauman DE \& Elliot JM (1983) Control of nutrient partitioning in lactating ruminants. In Biochemistry of Lactation, pp. 437-468 [TB Mepham, editor]. Amsterdam: Elsevier Science Publishers B.V.

42. Gagliostro G, Chilliard Y \& Davicco MJ (1991) Duodenal rapeseed oil infusion in early and midlactation cows. 3. Plasma hormones and mammary apparent uptake of metabolites. J Dairy Sci 74, 1893-1903.

43. Bonnet M, Delavaud C, Bernard L, et al. (2009) Sunflowerseed oil, rapidly-degradable starch, and adiposity upregulate leptin gene expression in lactating goats. Domest Anim Endocrinol 37, 93-103.

44. Biddinger SB, Miyazaki M, Boucher J, et al. (2006) Leptin suppresses stearoyl-CoA desaturase 1 by mechanisms independent of insulin and sterol regulatory element-binding protein-1c. Diabetes 55, 2032-2041.

45. Kawachi H, Yang SH, Hamano A, et al. (2007) Molecular cloning and expression of bovine (Bos taurus) leptin receptor isoform mRNAs. Comp Biochem Physiol B Biochem Mol Biol 148, 167-173.

46. Wylie ARG (2011) Leptin in farm animals: where are we and were can we go? Animal 5, 246-267.

47. Chilliard Y, Delavaud C \& Bonnet M (2005) Leptin expression in ruminants: nutritional and physiological regulations in relation with energy metabolism. Domest Anim Endocrinol 29, 3-22.

48. Jurie C, Cassar-Malek I, Bonnet M, et al. (2007) Adipocyte fatty acid-binding protein and mitochondrial enzyme activities in muscles as relevant indicators of marbling in cattle. J Anim Sci 85, 2660-2669.

49. Ollier S, Leroux C, Bernard L, et al. (2009) Whole intact rapeseeds or sunflower oil in high-forage or high-concentrate diets affects milk yield, milk composition and mammary gene expression profile in goats. J Dairy Sci 92, 5544-5560. 